\title{
Erratum to: A biomechanical comparison between cortical bone trajectory fixation and pedicle screw fixation
}

Hiroki Oshino ${ }^{1}$, Toshihiko Sakakibara ${ }^{2}$, Tadashi Inaba ${ }^{1}$, Takamasa Yoshikawa ${ }^{1}$, Takaya Kato ${ }^{3}$ and Yuichi Kasai ${ }^{2^{*}}$

\section{Erratum}

After publication of the original article [1] it came to our attention that the legends for figures 2 and 3 had been interchanged. The correct legend for figure two is 'Pedicle screw fusion model' and the correct legend for figure three is 'Cortical bone trajectory model'.

\footnotetext{
Author details

'Department of Mechanical Engineering, Mie University, Tsu City, Mie, Japan. ${ }^{2}$ Department of Spinal Surgery and Medical Engineering, Mie University Graduate School of Medicine, 2-174 Edobashi, Tsu City 514-8507, Mie, Japan. ${ }^{3}$ Community-University Research Cooperation Center, Mie University, Tsu City, Mie, Japan.
}

Received: 17 September 2015 Accepted: 17 September 2015 Published online: 24 September 2015

\section{Reference}

1. Oshino H, Sakakibara T, Inaba T, Yoshikawa T, Kato T, Kasai Y. A

biomechanical comparison between cortical bone trajectory fixation and pedicle screw fixation. J Orthop Surg Res. 2015;10:125.

\footnotetext{
* Correspondence: ykasai@clin.medic.mie-u.ac.jp

${ }^{2}$ Department of Spinal Surgery and Medical Engineering, Mie University Graduate School of Medicine, 2-174 Edobashi, Tsu City 514-8507, Mie, Japan
} Full list of author information is available at the end of the article

Submit your next manuscript to BioMed Central and take full advantage of:

- Convenient online submission

- Thorough peer review

- No space constraints or color figure charges

- Immediate publication on acceptance

- Inclusion in PubMed, CAS, Scopus and Google Scholar

- Research which is freely available for redistribution

Submit your manuscript at www.biomedcentral.com/submit 